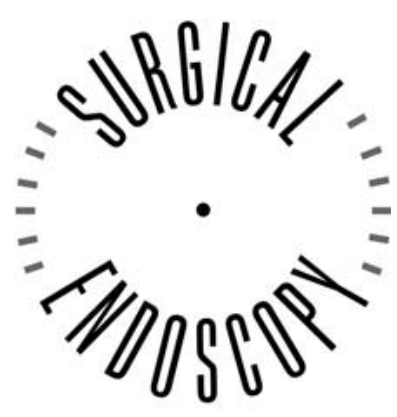

DOI: $10.1007 / \mathrm{s} 00464-004-0084-3$

(C) Springer Science+Business Media, Inc. 2004

and Other Interventional Techniques

\title{
Corona mortis
}

An anatomic study in seven cadavers and an endoscopic study in 28 patients

M. Berberoğlu, A. Uz, M. M. Özmen, M. C. Bozkurt, C. Erkuran, S. Taner, A. Tekin, İ. Tekdemir Ankara and Mersin, Turkey

[Surg Endosc (2001) 15: 72-75. DOI: 10.1007/s004640000194]

M. C. Bozkurt's name was published incorrectly and is corrected here. 